\section{CIENCIA y DESARROLLO}

Volumen 18 Número 2 Julio-Diciembre 2015

\section{UNIVERSIDAD ALAS PERUANAS}

Fidel Ramírez Prado Ph. D Rector

Dr. Jorge Lazo Arrasco Vicerrector de Investigación e Innovación

Dr. EnRique Bedoya SÁnchez Vicerrector Académico

Dr. Manuel Coronado Aguilar Vicerrector Administrativo

Dr. José Soberón Bolaños Vicerrector de Planificación y Economía

Director

Dr. Jaime Deza Rivasplata

Comité Editorial

Dr. Jorge Lazo Arrasco

Dr. Gerardo Ayzanoa del Carpio Experto de UNESCO y OEA

Dr. Enrique Bedoya Sánchez Ex vicepresidente de la Asamblea Nacional de Rectores

Comié Científico

Dr. Francisco Garcés García Sociedad Cubana de Microbiología

Dr. Artidoro Cáceres Velásques Doctor en medicina, neuropsicólogo y sexólogo

Dr. Victor Raúl Díaz Chávez Ex-ministro de Educacióm

Diseño y diagramación

Hector Abraham Saavedra Cavero

Dirección de Investigación de la Universidad Alas Peruanas

Av. Paseo de la República 1773.

La Victoria, Lima, Perú.

Teléfono: 265 5022, anexo 20

E-mail: cienciaydesarrollo@uap.edu.pe URL: http://revistas.uap.edu.pe/ojs/index. $\mathrm{php} / \mathrm{CYD} /$ index

ISSN versión impresa: 1994-7224

ISSN versión electrónica: 2409-2045

Depósito legal: 2000-2017

Revista indizada en base de datos LATINDEX Folio: 14856

Prohibida la reproducción total o parcial de los artículos publicados en esta revista. Los artículos publicados expresan las opiniones personales de sus autores y no

\section{CONTENIDO}

Saludo 5

\section{Articulos originales}

Efecto de la plata coloidal en la evolución de la cicatrización de heridas quirúrgicas abdominales en ratas albinas (Rattus norvegicus)

Colloidal silver effect in the evolution of surgical abdominal wound healing in albino rats (Rattus norvegicus)

Gisele Delgado, Diana Díaz, Claudia Zavala

Comparación in vitro de las propiedades físico - químicas de un ionómero de vidrio convencional, un cermet y un ionómero de vidrio modificado con aleación para amalgama

In vitro comparison of the physical - chemical properties of a conventional glass ionomer, a cermet and modified glass ionomer amalgam alloy

Herbert Cosio, Gladys Zúñiga, Maria Zvietcovich

Eficacia de un enjuagatorio comercial en comparación al enjuagatorio con cloruro de sodio al $5 \%$ en la disminución de Streptococcus mutans

Effectiveness of a commercial mouthwash compared to mouthwash with sodium chloride, 5\% decrease Streptococcus mutans

César Cayo, Sandra Salvador, javier Ramos

Control y tratamiento de sarna (Escabiosis) en vicuñas de la comunidad campesina de Lucanas - Reserva Nacional de Pampa Galeras. Ayacucho Perú

Control and treatment of mange (Scabies) in vicunas of the peasant community of Lucanas - Pampa Galeras National Reserve. Ayacucho Peru

Norma Bujaico, Marco Zuñiga 
Mejora de la velocidad de la marcha con la aplicación de un programa de fuerza muscular en adultos mayores sexagenarios.

Improving the speed of up to the implementation of a program of muscle strength in elderly sixties.

Lenin Mendieta, Rijkaard Mendieta, Jonh Marcelo, Darwin García

Higiene oral, grado de instrucción materna y su asociación con la caries en niños de 6 a 9 años

Oral hygiene, maternal level of education and their association with caries in children 6 to 9 years

Liceth Lazo, Herbert Cosio

Modelo sostenible CBC de gestión ambiental para desarrollar conciencia de cambio climático en la Universidad Alas Peruanas de Ica - 2012

$C B C$ sustainable environmental management model to develop awareness of climate change at the University Alas Peruanas de Ica - 2012

Carlos Blanco, Harry Lebeau

Técnicas de creatividad y capacidad creativa de los docentes de la Institución Educativade Nivel Inicial San Judas Tadeo del Distrito de Breña, Lima 2014

Creativity techniques and creative capacity of the teachers at the Educational Institution of Kinder Garden San Judas Tadeo from the Breña District, Lima 2014

Raúl Chávez , Alejandro Sánchez, Miguel Chumpitaz

Ensayos

Apantallamiento gravitatorio y agujeros negros

Gravitational screening and black holes

Álvarez, Enrique

Instrucciones para los autores 